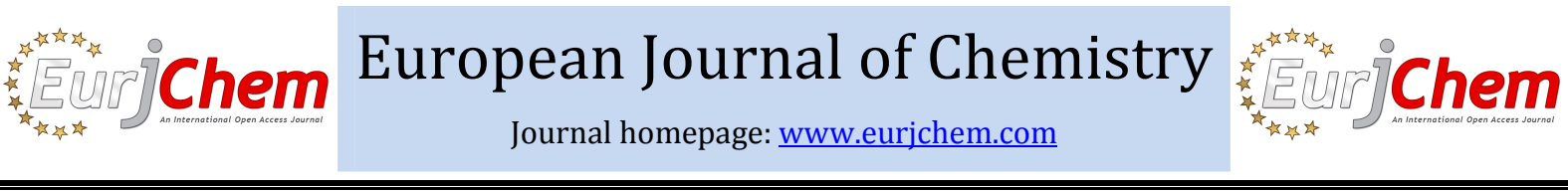

\section{Synthesis of new benzisoxazole derivatives and their antimicrobial, antioxidant and anti-inflammatory activities}

\author{
Chalya Mallappaji Shivaprasad, Swamy Jagadish, Toreshettahally Ramesh Swaroop, \\ Chakrabhavi Dhananjaya Mohan, Rangaswamy Roopashree, \\ Kothanahally Shivaramu Sharath Kumar and Kanchugarakoppal Subbegowda Rangappa*
}

Department of Studies in Chemistry, University of Mysore, Manasagangotri, Mysore, 570 006, India

*Corresponding author at: Department of Studies in Chemistry, University of Mysore, Manasagangotri, Mysore, 570 006, India. Tel.: +91.0821.2419661. Fax: +91.0821.2500846. E-mail address: rangappaks@uni-mysore.ac.in (K. S. Rangappa).

\section{ARTICLE INFORMATION}

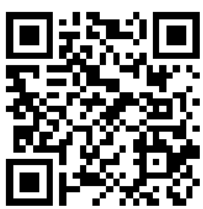

DOI: 10.5155 /eurjchem.5.1.91-95.866

Received: 05 July 2013

Received in revised form: 17 September 2013

Accepted: 22 September 2013

Online: 31 March 2014

\section{KEYWORDS}

\section{Piperidine}

Antioxidant

Spirolactone

Benzisoxazole

Antimicrobial

Anti-inflammatory

\section{Introduction}

Benzisoxazole derivatives are one of the most important heterocyclic system in the field of medicinal chemistry and associated with the wide range of biological activities such as antimicrobial [1], anticonvulsant [2,3], antitumor [4,5], antipsychotic [6-8], antithrombotic [9] analgesic activities [10]. They have also exhibited antiglycating [11] and cholinesteraseinhibiting properties [12-13]. Previously we have investigated various biological activities of these benzisoxazole derivatives as antimicrobial [1] and cholinesterase-inhibiting agents [13]. Recently, we have also reported some derivatives of piperidine conjugated benzisoxazole derivatives as antibacterial, antioxidant and anti-inflammatory agents [14]. In continuation of these works, we extended our efforts towards the synthesis of new benzisoxazolylpiperidinesulfonyl derivatives and the study of their antibacterial, antioxidant and anti-inflammatory activities.

\section{Experimental}

\subsection{Instrumentation}

The melting points were determined on Selaco melting point apparatus and are uncorrected. Infrared spectra were recorded on Shimadzu FT-IR model 8300 spectrophotometer. ${ }^{1} \mathrm{H}$ NMR spectra were recorded on an NMR spectrometer operating at $400 \mathrm{MHz}$ using TMS as internal standard. Mass spectra were recorded using electrospray ionization mass spectrometry. The $\mathrm{C}, \mathrm{H}$ and $\mathrm{N}$ analysis were performed using CE-400 CHN analyzer. Reactions were monitored by TLC using pre-coated sheets of silica gel G/UV-254 of $0.25 \mathrm{~mm}$ thickness (Merck $60 \mathrm{~F}_{254}$ ) using UV light for visualization. All chemicals were obtained from Aldrich, Fluka and Merck Chemicals.

\subsection{Synthesis}

8-Tert-butyl 4-methyl 3-methyl-2-oxo-1-oxa-8-azaspiro [4.5]dec-3-ene-4,8-dicarboxylate (3), 8-(tert-butoxycarbonyl)3-methyl-2-oxo-1-oxa-8-azaspiro[4.5] dec-3-ene-4-carboxylic acid (4), tert-butyl 4-(4-(6-fluorobenzo[d]isoxazol-3-yl)piperidine-1-carbonyl)-3-methyl-2-oxo-1-oxa-8-azaspiro[4.5]dec3-ene-8-carboxylate (6), 4-(4-(6-fluorobenzo[d]isoxazol-3-yl) piperidine-1-carbonyl)-3-methyl-1-oxa-8-azaspiro[4.5]dec-3en-2-one hydrochloride (7) are synthesized according to reference [14]. 


\begin{tabular}{llll}
\multicolumn{2}{l}{ Table 1. Derivatives of benzisoxazole. } & Compound & Yield (\%) \\
\hline Entry & $\mathbf{R}(\mathbf{8}, \mathbf{9})$ & $9 \mathrm{a}$ & 76 \\
\hline 1 & $4-\mathrm{MeC}_{6} \mathrm{H}_{4}$ & $9 \mathrm{~b}$ & 71 \\
2 & $2,5-\mathrm{Cl}_{2} \mathrm{C}_{6} \mathrm{H}_{3}$ & $9 \mathrm{c}$ & 75 \\
3 & $4-\mathrm{MeOC}_{6} \mathrm{H}_{4}$ & $9 \mathrm{~d}$ & 80 \\
4 & $\mathrm{C}_{6} \mathrm{H}_{5}$ & $9 \mathrm{e}$ & 65 \\
5 & $4-\mathrm{FC}_{6} \mathrm{H}_{4}$ & $9 \mathrm{f}$ & 74 \\
6 & $2-\mathrm{NO}_{2} \mathrm{C}_{6} \mathrm{H}_{4}$ & 68 \\
7 & $4-\mathrm{NO}_{2} \mathrm{C}_{6} \mathrm{H}_{4}$ & $9 \mathrm{~g}$ & 79 \\
8 & $4-\mathrm{ClC}_{6} \mathrm{H}_{4}$ & $9 \mathrm{~h}$ & \\
\hline
\end{tabular}<smiles>C=C(CC(=O)OC)C(=O)OC</smiles>

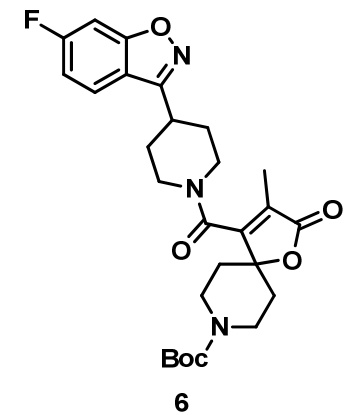

Reagents and reaction conditions: (a) MeONa/THF, $0{ }^{\circ} \mathrm{C}-\mathrm{RT}$, $8 \mathrm{~h}$. (b) LiOH/MeOH/ $\mathrm{H}_{2} \mathrm{O}, 0{ }^{\circ} \mathrm{C}-\mathrm{RT}, 3 \mathrm{~h}$. (c) 6-fluoro-3-(piperidin-4-yl)benzo[d]isoxazole hydrochloride 5, EDC.HCl/HOBt/DIPEA $/ \mathrm{CH}_{2} \mathrm{Cl}_{2}, 0^{\circ} \mathrm{C}-\mathrm{RT}$, 8 h. (d) $\mathrm{HCl} /$ ether, $0{ }^{\circ} \mathrm{C}-\mathrm{RT}$, $1 \mathrm{~h}$. (e) $\mathrm{RSO}_{2} \mathrm{Cl} \mathrm{8}$, TEA/EDC, $0{ }^{\circ} \mathrm{C}-\mathrm{RT}, 3-4 \mathrm{~h}$.

Scheme 1

\subsubsection{General procedure for the synthesis of compounds $9 a-$} h

To a solution of compound 7 (5 mmol) and triethyl amine (5 mmol) in dichloromethane $(20 \mathrm{~mL})$; sulfonyl chloride 8 (5 mmol) was added at $0{ }^{\circ} \mathrm{C}$ and stirred at room temperature for 3-4 h. After the completion of the reaction, $20 \mathrm{~mL}$ of water was added and extracted the reaction mixture with dichloromethane $(20 \mathrm{~mL} \times 2)$. The organic layer was concentrated under reduced pressure to get products 9 (Scheme 1, Table 1) which were purified by column chromatography using $\mathrm{CHCl}_{3}: \mathrm{MeOH}(9: 1, v: v)$ as eluent.

4-(4-(6-Fluorobenzo[d]isoxazol-3-yl)piperidine-1-carbonyl)3-methyl-8-tosyl-1-oxa-8-azaspiro[4.5]dec-3-en-2-one (9a): Colour: White. Yield: $76 \%$. M.p.: $104-106{ }^{\circ} \mathrm{C}$. FT-IR (KBr, v, $\mathrm{cm}^{-1}$ ): 1660 (Amide CO str.), 1740 (Ester CO str.), 3045 (Ar. CH str.). ${ }^{1} \mathrm{H}$ NMR ( $\left.400 \mathrm{MHz}, \mathrm{CDCl}_{3}, \delta, \mathrm{ppm}\right): 8.09(\mathrm{~d}, 2 \mathrm{H}, J=7.8 \mathrm{~Hz}$, Ar-H), $7.78(\mathrm{~d}, 2 \mathrm{H}, J=8.2 \mathrm{~Hz}, \mathrm{Ar}-\mathrm{H}), 7.64(\mathrm{~d}, 1 \mathrm{H}, J=7.2 \mathrm{~Hz}, \mathrm{Ar}-$ H), 7.26 (d, $1 \mathrm{H}, J=7.2 \mathrm{~Hz}, \mathrm{Ar}-\mathrm{H}), 7.05(\mathrm{~s}, 1 \mathrm{H}, \mathrm{Ar}-\mathrm{H}), 3.30-3.39$ $\left(\mathrm{m}, 8 \mathrm{H}, \mathrm{CH}_{2}\right), 2.75(\mathrm{~m}, 1 \mathrm{H}, \mathrm{CH}), 2.54\left(\mathrm{~s}, 3 \mathrm{H}, \mathrm{CH}_{3}\right), 2.35$ (S, 3H, Ar$\mathrm{Me}), 1.65-1.90\left(\mathrm{~m}, 8 \mathrm{H}, \mathrm{CH}_{2}\right)$. MS (ESI, $\left.m / z\right)$ : $568(\mathrm{M}+1)$. Anal. calcd. for $\mathrm{C}_{29} \mathrm{H}_{30} \mathrm{FN}_{3} \mathrm{O}_{6} \mathrm{~S}: \mathrm{C}, 61.36$; $\mathrm{H}, 5.33$; N, 7.40. Found: $\mathrm{C}$, 61.41; H, 5.39; N, 7.47\%.

8-((2,5-Dichlorophenyl)sulfonyl)-4-(4-(6-fluorobenzo[d]iso xazol-3-yl)piperidine-1-carbonyl)-3-methyl-1-oxa-8-azaspiro [4.5]dec-3-en-2-one (9b): Colour: White. Yield: 71\%. M.p.: 110$112{ }^{\circ} \mathrm{C}$. FT-IR (KBr, $v, \mathrm{~cm}^{-1}$ ): 1655 (Amide CO str.), 1756 (Ester CO str.), 3049 (Ar. CH str.). ${ }^{1} \mathrm{H}$ NMR ( $400 \mathrm{MHz}, \mathrm{CDCl}_{3}, \delta$, ppm): 7.77 (s, 1H, Ar-H), 7.469-7.55 (m, 3H, Ar-H), 7.28 (d, $1 \mathrm{H}, J=7.8$ $\mathrm{Hz}, \operatorname{Ar}-\mathrm{H}), 7.03(\mathrm{~s}, 1 \mathrm{H}, \mathrm{Ar}-\mathrm{H}), 3.25-3.35\left(\mathrm{~m}, 8 \mathrm{H}, \mathrm{CH}_{2}\right), 2.72(\mathrm{~m}$,
$1 \mathrm{H}, \mathrm{CH}), 2.50\left(\mathrm{~s}, 3 \mathrm{H}, \mathrm{CH}_{3}\right), 1.62-1.88\left(\mathrm{~m}, 8 \mathrm{H}, \mathrm{CH}_{2}\right) . \mathrm{MS}$ (ESI, $m / z$ ): $623(\mathrm{M}+1)$. Anal. calcd. for $\mathrm{C}_{28} \mathrm{H}_{26} \mathrm{Cl}_{2} \mathrm{FN}_{3} \mathrm{O}_{6} \mathrm{~S}: \mathrm{C}, 54.02 ; \mathrm{H}$, 4.21; N, 6.75. Found: C, 54.09; H, 4.26; N, 6.81\%.

4-(4-(6-Fluorobenzo[d]isoxazol-3-yl)piperidine-1-carbonyl)8-((4-methoxyphenyl)sulfonyl)-3-methyl-1-oxa-8-azaspiro[4.5] dec-3-en-2-one (9c): Colour: White. Yield: 75\% (2.18 g). M.p.: 98-100 ${ }^{\circ} \mathrm{C}$. FT-IR (KBr, v, cm-1): 1659 (Amide CO str.), 1782 (Ester CO str.), 3047 (Ar. CH str.). ${ }^{1} \mathrm{H}$ NMR $\left(400 \mathrm{MHz}, \mathrm{CDCl}_{3}, \delta\right.$, ppm): 7.91 (d, $2 \mathrm{H}, J=8.0 \mathrm{~Hz}, \mathrm{Ar}-\mathrm{H}), 7.56$ (d, 1H, $J=7.6 \mathrm{~Hz}, \mathrm{Ar}-$ $\mathrm{H})$, 7.15-7.24 (m, 3H, Ar-H), $6.97(\mathrm{~s}, 1 \mathrm{H}, \mathrm{Ar}-\mathrm{H}), 3.82(\mathrm{~s}, 3 \mathrm{H}$, OMe), 3.32-3.45 (m, 8H, CH 2$), 2.66(\mathrm{~m}, 1 \mathrm{H}, \mathrm{CH}), 2.52(\mathrm{~s}, 3 \mathrm{H}$, $\left.\mathrm{CH}_{3}\right), 1.62-1.85\left(\mathrm{~m}, 8 \mathrm{H}, \mathrm{CH}_{2}\right)$. MS (ESI, $\left.m / z\right): 584(\mathrm{M}+1)$. Anal. calcd. for $\mathrm{C}_{29} \mathrm{H}_{30} \mathrm{FN}_{3} \mathrm{O}_{7} \mathrm{~S}$ : C, 59.68; $\mathrm{H}, 5.18 ; \mathrm{N}, 7.20$. Found: $\mathrm{C}$, 59.75; H, 5.26; N, 7.29\%.

4-(4-(6-Fluorobenzo[d]isoxazol-3-yl)piperidine-1-carbonyl)3-methyl-8-(phenylsulfonyl)-1-oxa-8-azaspiro[4.5]dec-3-en-2one (9d): Colour: White. Yield: $80 \%$. M.p.: $120-122{ }^{\circ} \mathrm{C}$. FT-IR (KBr, v, cm-1): 1659 (Amide CO str.), 1765 (Ester CO str.), 3055 (Ar. CH str.). ${ }^{1} \mathrm{H}$ NMR $\left(400 \mathrm{MHz}, \mathrm{CDCl}_{3}, \delta, \mathrm{ppm}\right): 8.26(\mathrm{~s}, 1 \mathrm{H}, \mathrm{Ar}-$ $\mathrm{H}), 8.04(\mathrm{~d}, 1 \mathrm{H}, J=7.8 \mathrm{~Hz}, \mathrm{Ar}-\mathrm{H}), 7.95$ (d, $1 \mathrm{H}, J=7.6 \mathrm{~Hz}, \mathrm{Ar}-\mathrm{H})$, $7.58(\mathrm{~m}, 2 \mathrm{H}, \mathrm{Ar}-\mathrm{H}), 7.28(\mathrm{~m}, 2 \mathrm{H}, \mathrm{Ar}-\mathrm{H}), 7.05(\mathrm{~s}, 1 \mathrm{H}, \mathrm{Ar}-\mathrm{H}), 3.25-$ $3.35\left(\mathrm{~m}, 8 \mathrm{H}, \mathrm{CH}_{2}\right), 2.70(\mathrm{~m}, 1 \mathrm{H}, \mathrm{CH}), 2.52\left(\mathrm{~s}, 3 \mathrm{H}, \mathrm{CH}_{3}\right), 1.60-1.84$ $\left(\mathrm{m}, 8 \mathrm{H}, \mathrm{CH}_{2}\right)$. MS (ESI, $\left.\mathrm{m} / \mathrm{z}\right)$ : $554(\mathrm{M}+1)$. Anal. calcd. for $\mathrm{C}_{28} \mathrm{H}_{28} \mathrm{FN}_{3} \mathrm{O}_{6} \mathrm{~S}: \mathrm{C}, 60.75 ; \mathrm{H}, 5.10$; N, 7.59. Found: C, 60.82; $\mathrm{H}$, $5.18 ; \mathrm{N}, 7.65 \%$.

4-(4-(6-Fluorobenzo[d]isoxazol-3-yl)piperidine-1-carbonyl)8-((4-fluorophenyl)sulfonyl)-3-methyl-1-oxa-8-azaspiro[4.5]dec3-en-2-one (9e): Colour: White. Yield: $65 \%$. M.p.: $110-112{ }^{\circ} \mathrm{C}$. FT-IR (KBr, v, $\mathrm{cm}^{-1}$ ): 1665 (Amide CO str.), 1755 (Ester CO str.), 3068 (Ar. CH str.). 
Table 2. Antibacterial activity of benzisoxazoles $\mathbf{9 a - h}$.

\begin{tabular}{|c|c|c|c|c|c|}
\hline \multirow[t]{2}{*}{ Compound } & \multicolumn{5}{|c|}{ Zone of inhibition in millimetre * } \\
\hline & Escherichia coli & Bacillus subtilis & Klebsiella pneumoniae & Salmonella typhi & Shigella flexneri \\
\hline$\overline{9 a}$ & 11 & 10 & 11 & 10 & - \\
\hline $9 b$ & 12 & - & 14 & 12 & - \\
\hline $9 c$ & 12 & 10 & 12 & 12 & - \\
\hline $9 d$ & 13 & 10 & 22 & 19 & 13 \\
\hline $9 e$ & 11 & 11 & 16 & 18 & - \\
\hline 9f & 11 & 13 & 9 & 14 & 10 \\
\hline $9 g$ & 11 & - & 10 & 10 & - \\
\hline $9 \mathrm{~h}$ & 12 & 10 & 12 & 11 & - \\
\hline
\end{tabular}

Table 3 Antioxidant activity of benzisoxazoles $\mathbf{9 a - h}$.

\begin{tabular}{|c|c|c|c|}
\hline \multirow[t]{2}{*}{ Compounds } & \multicolumn{3}{|l|}{$\mathrm{IC}_{50}$ values in $\mu \mathrm{M}$} \\
\hline & DPPH radical Scavenging Assay & Hydroxyl radical Scavenging assay & Superoxide radical scavenging assay \\
\hline$\overline{9 a}$ & 3.8 & 3.7 & 2.3 \\
\hline $9 \mathrm{~b}$ & 7.4 & 7.6 & 5.0 \\
\hline $9 \mathrm{c}$ & 4.0 & 4.1 & 2.5 \\
\hline $9 d$ & 6.8 & 7.0 & 6.9 \\
\hline $9 \mathrm{e}$ & 8.8 & 7.8 & 9.4 \\
\hline $9 \mathrm{f}$ & 5.4 & 5.7 & 7.0 \\
\hline $9 g$ & 5.2 & 4.7 & 6.6 \\
\hline $9 \mathrm{~h}$ & 7.0 & 6.6 & 4.3 \\
\hline Ascorbic acid & 3.5 & 3.4 & 2.8 \\
\hline
\end{tabular}

${ }^{1} \mathrm{H}$ NMR (400 MHz, $\left.\mathrm{CDCl}_{3}, \delta, \mathrm{ppm}\right): 8.24(\mathrm{~s}, 1 \mathrm{H}, \mathrm{Ar}-\mathrm{H}), 8.04$ (d, $1 \mathrm{H}, J=7.8 \mathrm{~Hz}, \mathrm{Ar}-\mathrm{H}), 7.97$ (d, 1H, J = $7.6 \mathrm{~Hz}, \mathrm{Ar}-\mathrm{H}), 7.54(\mathrm{~m}$, $2 \mathrm{H}, \mathrm{Ar}-\mathrm{H}), 7.24(\mathrm{~m}, 1 \mathrm{H}, \mathrm{Ar}-\mathrm{H}), 7.02(\mathrm{~s}, 1 \mathrm{H}, \mathrm{Ar}-\mathrm{H}), 3.25-3.36(\mathrm{~m}$, $\left.8 \mathrm{H}, \mathrm{CH}_{2}\right), 2.71(\mathrm{~m}, 1 \mathrm{H}, \mathrm{CH}), 2.52\left(\mathrm{~s}, 3 \mathrm{H}, \mathrm{CH}_{3}\right), 1.61-1.83(\mathrm{~m}, 8 \mathrm{H}$, $\left.\mathrm{CH}_{2}\right)$. MS (ESI, $\left.m / z\right): 572(\mathrm{M}+1)$. Anal. calcd. for $\mathrm{C}_{28} \mathrm{H}_{27} \mathrm{~F}_{2} \mathrm{~N}_{3} \mathrm{O}_{6} \mathrm{~S}$ : C, 58.84; H, 4.76; N, 7.35. Found: C, 58.89; H, 4.81; N, 7.41\%.

4-(4-(6-Fluorobenzo[d]isoxazol-3-yl)piperidine-1-carbonyl)3-methyl-8-((2-nitrophenyl)sulfonyl)-1-oxa-8-azaspiro[4.5]dec3-en-2-one (9f): Colour: White. Yield: $74 \%$. M.p.: $134-136{ }^{\circ} \mathrm{C}$. FT-IR ( $\mathrm{KBr}, v, \mathrm{~cm}^{-1}$ ): 1665 (Amide CO str.), 1771 (Ester CO str.), 3032 (Ar. CH str.). ${ }^{1} \mathrm{H}$ NMR (400 MHz, $\left.\mathrm{CDCl}_{3}, \delta, \mathrm{ppm}\right): 9.02$ (d, $2 \mathrm{H}, J=2.8 \mathrm{~Hz}, \mathrm{Ar}-\mathrm{H}), 8.94(\mathrm{~m}, 2 \mathrm{H}, \mathrm{Ar}-\mathrm{H}), 7.56(\mathrm{~d}, 1 \mathrm{H}, J=7.2 \mathrm{~Hz}$, Ar-H), $7.33(\mathrm{~d}, 1 \mathrm{H}, J=7.2 \mathrm{~Hz}, \mathrm{Ar}-\mathrm{H}), 7.02(\mathrm{~s}, 1 \mathrm{H}, \mathrm{Ar}-\mathrm{H}), 3.26-3.39$ $\left(\mathrm{m}, 8 \mathrm{H}, \mathrm{CH}_{2}\right), 2.72(\mathrm{~m}, 1 \mathrm{H}, \mathrm{CH}), 2.49\left(\mathrm{~s}, 3 \mathrm{H}, \mathrm{CH}_{3}\right), 1.66-1.81(\mathrm{~m}$, $\left.8 \mathrm{H}, \mathrm{CH}_{2}\right)$. MS (ESI, $\left.m / z\right)$ : $599(\mathrm{M}+1)$. Anal. calcd. for $\mathrm{C}_{28} \mathrm{H}_{27} \mathrm{FN}_{4} \mathrm{O}_{8} \mathrm{~S}$ : C, 56.18; $\mathrm{H}, 4.55$; N, 9.36. Found: C, 56.26; $\mathrm{H}$, $4.62 ; \mathrm{N}, 9.42 \%$.

4-(4-(6-Fluorobenzo[d]isoxazol-3-yl)piperidine-1-carbonyl)3-methyl-8-((4-nitrophenyl)sulfonyl)-1-oxa-8-azaspiro[4.5]dec3-en-2-one (9g): Colour: White. Yield: 68\%. M.p.: $140-142{ }^{\circ} \mathrm{C}$. FT-IR (KBr, $v, \mathrm{~cm}^{-1}$ ): 1669 (Amide CO str.), 1771 (Ester CO str.), 3061 (Ar. CH str.). ${ }^{1} \mathrm{H}$ NMR ( $400 \mathrm{MHz}, \mathrm{CDCl}_{3}, \delta$, ppm): 8.71 (s, $1 \mathrm{H}, \mathrm{Ar}-\mathrm{H}), 8.53$ (d, $1 \mathrm{H}, J=8.0 \mathrm{~Hz}, \mathrm{Ar}-\mathrm{H}), 8.43$ (d, $1 \mathrm{H}, J=8.0 \mathrm{~Hz}$, Ar-H), 7.89 (t, $1 \mathrm{H}, J=7.8 \mathrm{~Hz}, \mathrm{Ar}-\mathrm{H}), 7.56(\mathrm{~d}, 1 \mathrm{H}, J=7.2 \mathrm{~Hz}, \mathrm{Ar}-\mathrm{H})$, $7.26(\mathrm{~d}, 1 \mathrm{H}, J=7.3 \mathrm{~Hz}, \mathrm{Ar}-\mathrm{H}), 6.96(\mathrm{~s}, 1 \mathrm{H}, \mathrm{Ar}-\mathrm{H}), 3.27-3.42(\mathrm{~m}$, $\left.8 \mathrm{H}, \mathrm{CH}_{2}\right), 2.67(\mathrm{~m}, 1 \mathrm{H}, \mathrm{CH}), 2.47\left(\mathrm{~s}, 3 \mathrm{H}, \mathrm{CH}_{3}\right), 1.68-1.82(\mathrm{~m}, 8 \mathrm{H}$, $\mathrm{CH}_{2}$ ). MS (ESI, $\left.m / z\right)$ : $599(\mathrm{M}+1)$. Anal. calcd. for $\mathrm{C}_{29} \mathrm{H}_{27} \mathrm{FN}_{4} \mathrm{O}_{8}$ : C, 56.18; H, 4.55; N, 9.36. Found: C, 56.28; H, 4.64; N, 9.45\%.

8-((4-Chlorophenyl)sulfonyl)-4-(4-(6-fluorobenzo[d]isoxazol3-yl)piperidine-1-carbonyl)-3-methyl-1-oxa-8-azaspiro[4.5]dec3-en-2-one $(\mathbf{9 h})$ : Colour: White. Yield: $79 \%$. M.p.: $128-130{ }^{\circ} \mathrm{C}$. FT-IR ( $\mathrm{KBr}, v, \mathrm{~cm}^{-1}$ ): 1667 (Amide CO str.), 1774 (Ester CO str.), 3059 (Ar. CH str.). ${ }^{1} \mathrm{H}$ NMR ( $\left.400 \mathrm{MHz}, \mathrm{CDCl}_{3}, \delta, \mathrm{ppm}\right): 7.53-7.58$ (m, 2H, Ar-H), 7.19-7.25 (m, 4H, Ar-H), 6.95 (s, 1H, Ar-H), 3.31$3.45\left(\mathrm{~m}, 8 \mathrm{H}, \mathrm{CH}_{2}\right), 2.71(\mathrm{~m}, 1 \mathrm{H}, \mathrm{CH}), 2.53\left(\mathrm{~s}, 3 \mathrm{H}, \mathrm{CH}_{3}\right), 1.62-1.85$ $\left(\mathrm{m}, 8 \mathrm{H}, \mathrm{CH}_{2}\right)$. MS (ESI, $\left.m / z\right)$ : $588(\mathrm{M}+1)$. Anal. calcd. for $\mathrm{C}_{28} \mathrm{H}_{27} \mathrm{ClFN}_{3} \mathrm{O}_{6} \mathrm{~S}$ : C, $57.19 ; \mathrm{H}, 4.63 ; \mathrm{N}, 7.15$. Found: $\mathrm{C}, 57.26 ; \mathrm{H}$, 4.69; N, 7.21\%.

\subsection{Biological evaluation-antibacterial, antioxidant and anti-inflammatory activities}

\subsubsection{Antibacterial activity}

Antibacterial tests were carried out by disc diffusion method using $100 \mu \mathrm{L}$ of suspension containing $10^{6}$ cells $/ \mathrm{mL}$ of bacteria. The discs (6 $\mathrm{mm}$ diameter) were impregnated with 5 $\mathrm{mg}$ and $10 \mathrm{mg} / \mathrm{mL}$ of each compound and placed on the inoculated nutrient agar. Then, the inoculated plates were incubated at $37 \pm 0.1{ }^{\circ} \mathrm{C}$ at $24 \mathrm{~h}$. One antibacterial drug, chloramphenicol was used as positive control. Antibacterial activity was evaluated by measuring the zone of inhibition against the test organisms and the results are summarised in Table 2.

\subsubsection{Antioxidant activity}

\subsubsection{DPPH radical scavenging assay}

DPPH radical scavenging assays [15] were performed in $300 \mu \mathrm{L}$ reaction mixtures containing $200 \mu \mathrm{L}$ of $0.1 \mathrm{mM} \mathrm{DPPH}-$ ethanol solution, $90 \mu \mathrm{L}$ of $50 \mathrm{mM}$ Tris- $\mathrm{HCl}$ buffer $(\mathrm{pH}=7.4)$, and $10 \mu \mathrm{L}$ of deionised water (as control) and various concentrations of compounds 9a-h (1.7-8.8 $\mu \mathrm{g} / \mathrm{mL})$. Ascorbic acid was used as a standard. After $30 \mathrm{~min}$ of incubation at room temperature, absorbance $(540 \mathrm{~nm})$ of the reaction mixtures was taken by a plate reader (Lab systems Mullikan MS). The percentage radical scavenging activity was calculated according to the following formula:

Inhibition (\%) = (Absorbance control-Absorbance Sample $)$ Absorbance Control) $\times 100$

The DPPH radical scavenging activity is demonstrated in Figure 1 and Table 3.

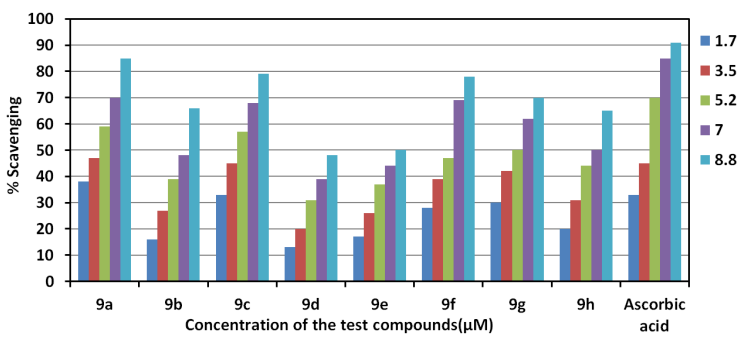

Figure 1. DPPH radical scavenging assay. 
Table 4. Anti-inflammatory activity of benzisoxazoles $\mathbf{9 a - h}$ *

\begin{tabular}{|c|c|c|}
\hline \multirow[t]{2}{*}{ Compounds } & \multicolumn{2}{|l|}{ IC $_{50}$ values in $\mu \mathrm{M}$} \\
\hline & Lipoxygenase inhibition assay & PLA $_{2}$ inhibition assay \\
\hline $9 a$ & 3.4 & 44.0 \\
\hline $9 b$ & 7.8 & 68.4 \\
\hline $9 \mathrm{c}$ & 3.7 & 50.4 \\
\hline $9 d$ & 9.5 & 76.6 \\
\hline $9 e$ & 7.8 & 73.1 \\
\hline 9f & 4.0 & 46.4 \\
\hline $9 \mathrm{~g}$ & 3.7 & 35.0 \\
\hline $9 \mathrm{~h}$ & 6.5 & 56.3 \\
\hline Indomethacin & 3.5 & - \\
\hline Aristolochic acid & - & 30.0 \\
\hline
\end{tabular}

Aristolochic acid

*"-"= Not determined

\subsubsection{Hydroxyl radical scavenging assay}

The reaction mixture in final volume of $2 \mathrm{~mL}$ containing 0.1 $\mathrm{mL}$ of EDTA $(1 \mathrm{mM}), 0.01 \mathrm{~mL}$ of $\mathrm{FeCl}_{3}(10 \mathrm{mM}), 0.1 \mathrm{~mL}$ of $\mathrm{H}_{2} \mathrm{O}_{2}$ $(10 \mathrm{mM}), 0.36 \mathrm{~mL}$ of deoxyribose $(10 \mathrm{mM}), 1 \mathrm{~mL}$ of the compounds 9a-h (concentrations from 1.7-8.8 $\mu \mathrm{g} / \mathrm{mL}$ ), $0.33 \mathrm{~mL}$ of phosphate buffer $(50 \mathrm{mM}, \mathrm{pH}=7.4)$ and $0.1 \mathrm{~mL}$ ascorbic acid $(1 \mathrm{mM})$ added in sequence. The mixture was incubated at $37^{\circ} \mathrm{C}$ for $1 \mathrm{~h} .1 \mathrm{~mL}$ of the incubated mixture was mixed with $1 \mathrm{~mL}$ of $10 \%$ trichloro acetic acid and $1 \mathrm{~mL}$ of TBA $(1 \%$ in $0.025 \mathrm{M}$ $\mathrm{NaOH}$ ), the resulting mixture was incubated in water bath at 90 ${ }^{\circ} \mathrm{C}$ for $20 \mathrm{~min}$ to develop a pink chromogen which was measured at $532 \mathrm{~nm}$ [16]. Ascorbic acid was used as a positive control. Percentage inhibition was evaluated by using the equation

Inhibition (\%) = (Absorbance control-Absorbance Sample) Absorbance Control) $\times 100$

The potency of benzisoxazoles for hydroxyl radical scavenging activity is illustrated in Figure 2 and Table 3.

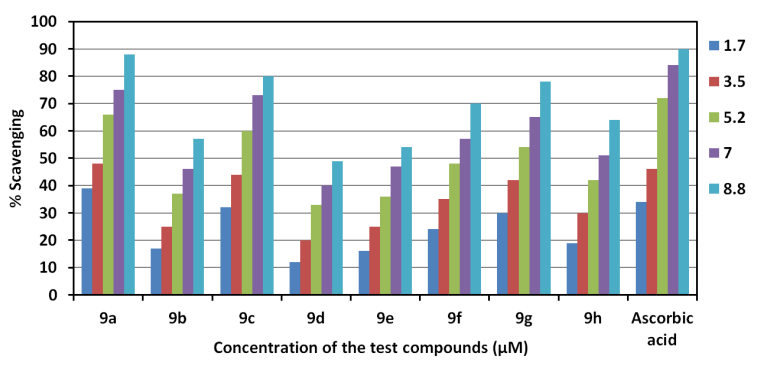

Figure 2. Hydroxyl radical scavenging assay.

\subsubsection{Superoxide anion radical scavenging assay}

The percentage inhibition of superoxide radical at $1 \mathrm{~mL}$ of NBT $(156 \mu \mathrm{M}$ NBT in $100 \mathrm{mM}$ phosphate buffer of $\mathrm{pH}=7.4), 1$ $\mathrm{mL}$ of NADH ( $468 \mu \mathrm{M}$ in $100 \mathrm{mM}$ phosphate buffer of $\mathrm{pH}=7.4)$ and varying concentration of compounds $\mathbf{9 a}-\mathbf{h}(1.1-5.8 \mu \mathrm{g} / \mathrm{mL})$ were mixed to give a final volume of $3 \mathrm{~mL}$. The reaction was started by the addition of $100 \mu \mathrm{L}$ of PMS $(60 \mu \mathrm{M}$ in $100 \mathrm{mM}$ phosphate buffer of $\mathrm{pH}=7.4$ ). The reaction mixture was incubated at $25^{\circ} \mathrm{C}$ for $5 \mathrm{~min}$ and the absorbance was measured at $560 \mathrm{~nm}$. Ascorbic acid was used as a standard [17]. Decreased absorbance of the reaction mixture indicated increased superoxide anion scavenging activity and it is illustrated in Figure 3 and Table 3.

\subsubsection{Anti-inflammatory activity}

\subsubsection{Lipoxygenase inhibition assay}

Lipoxygenase inhibition assay [18] was carried out using linoleic acid as substrate and lipoxgenase enzyme. To a solution of $0.1 \mathrm{~mL}$ of $2 \mathrm{M}$ borate buffer ( $\mathrm{pH}=9.0$ ), $0.1 \mathrm{~mL}$ of 1000 units lipoxidase enzyme, solution of compounds 9a-h in DMSO (1 $\mathrm{mg} / \mathrm{mL}$ ) was added and incubated with the enzyme with various concentrations. The tubes were agitated and incubated at room temperature for $5 \mathrm{~min}$, after which $2.0 \mathrm{~mL}$ of substrate solution, $0.6 \mathrm{mM}$ linoleum acid were added, mixed well and the absorbance was measured spectrophotometrically for $4 \mathrm{~min}$ at $234 \mathrm{~nm}$ (Shimadzu-2401 PC). Indomethacin was used as a reference standard drug. Percentage (\%) inhibition was calculated by the following equation

Inhibition $(\%)=($ Absorbance control-Absorbance Sample $)$ Absorbance Control) $\times 100$

The lipoxygenase inhibition activity of benzisoxazole is summarised in Table 4 and Figure 4.

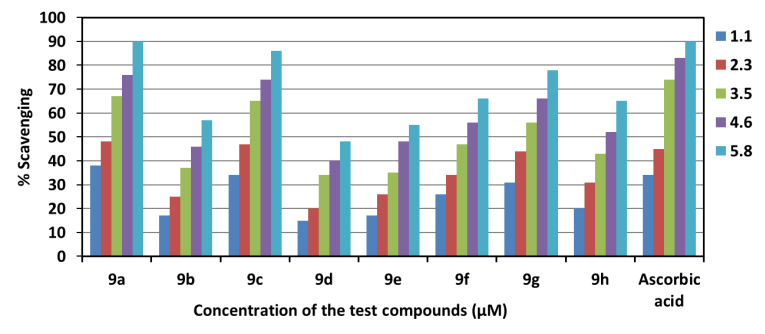

Figure 3. Superoxide radical scavenging assay.

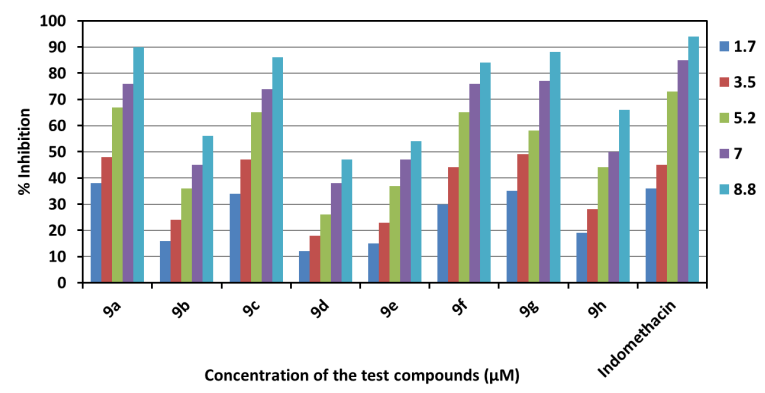

Figure 4. Lipoxygenase inhibition assay.

\subsubsection{Inhibition of $P L A_{2}$ induced haemolysis in human erythrocytes}

The substrate for indirect hemolytic activity was prepared by suspending $1 \mathrm{~mL}$ of fresh human red blood cells and $1 \mathrm{~mL}$ of fresh Hen's egg yolk in $8 \mathrm{~mL}$ of phosphate buffered saline. $1 \mathrm{~mL}$ of suspension was incubated with 4-28 $\mu \mathrm{g}$ of partially purified venom for $45 \mathrm{~min}$ at $37^{\circ} \mathrm{C}$ and the reaction was stopped by the 
addition of $9 \mathrm{~mL}$ of ice cold PBS. The suspension was centrifuged at $2000 \mathrm{rpm}$ for $20 \mathrm{~min}$ and then the released haemoglobin was read at $540 \mathrm{~nm}$. $10 \mu \mathrm{g}$ of venom sample

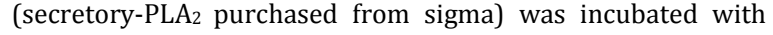
various concentration of compounds $\mathbf{9 a}-\mathbf{h}(1 \mathrm{mg} / \mathrm{mL}$ in DMSO) for 30 mins at room temperature and $1 \mathrm{~mL}$ of substrate was added, again incubated for $30 \mathrm{mins}$ at room temperature and the reaction was stopped by adding $9 \mathrm{~mL}$ of ice cold PBS to all test tubes and centrifuged at $2000 \mathrm{rpm}$ for 10 mins. Finally absorbance was measured at $540 \mathrm{~nm}$ [19] and inhibitory activities are summarised in Table 4 and Figure 5.

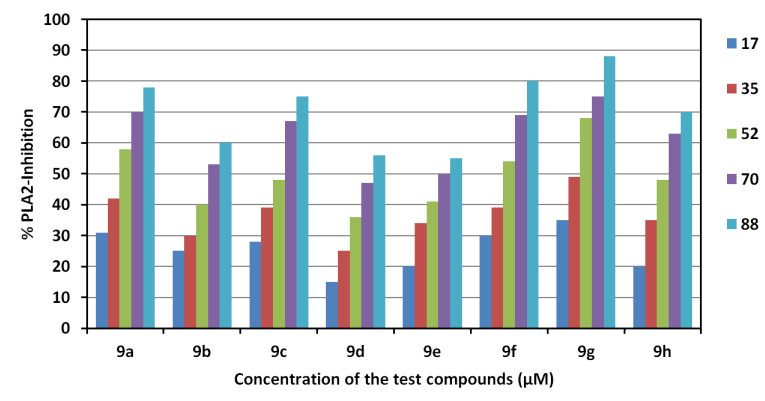

Figure 5. Inhibition of PLA2 induced haemolysis.

\section{Results and discussion}

The key intermediate 4-(4-(6-fluorobenzo[d]isoxazol-3-yl) piperidine-1-carbonyl)-3-methyl-1-oxa-8-azaspiro[4.5]dec-3en-2-one hydrochloride 7 was prepared according to our earlier reported procedure [14]. Thus, cyclocondensation of tert-butyl 4-oxopiperidine-1-carboxylate, 1, with dimethyl 2methylenesuccinate, $\mathbf{2}$, in presence of sodium methoxide in THF gave 8-tert-butyl 4-methyl 3-methyl-2-oxo-1-oxa-8azaspiro[4.5]dec-3-ene-4,8-dicarboxylate, $\mathbf{3}$, in $70 \%$ yield. Selective hydrolysis of methyl ester group in compound $\mathbf{3}$ by lithium hydroxide in methonolic water was carried out to get 8(tert-butoxycarbonyl)-3-methyl-2-oxo-1-oxa-8-azaspiro[4.5] dec-3-ene-4-carboxylic acid, 4, in 89\% yield. Condensation of compound 4 with 6-fluoro-3-(piperidin-4-yl)benzo[d]isoxazole hydrochloride, 5, [20] in presence of 1-ethyl-3-(3-dimethylaminopropyl)carbodiimide hydrochloride (EDC.HCl) and hydroxyl benzotriazole (HOBt) in dichloromethane to afford tert-butyl 4-(4-(6-fluorobenzo[d] isoxazol-3-yl)piperi-dine-1carbonyl)-3-methyl-2-oxo-1-oxa-8-azaspiro[4,5]dec-3-ene-8carboxylate, $\mathbf{6}$. Cleavage of tert-butyl oxy group in compound $\mathbf{6}$ by saturated solution of hydrochloric acid in ether to give the key intermediate 4-(4-(6-fluorobenzo[d]isoxazol-3-yl)piperidine-1-carbonyl)-3-methyl-1-oxa-8-azaspiro[4.5]dec-3-en-2one hydrochloride, 7. Sulfonation of compound $\mathbf{7}$ was carried out with various sulfonyl chlorides $\mathbf{8}$ to get final products $\mathbf{9}$.

All compounds showed moderate antibacterial activity against Escherichia coli, Klebsiella pneumonia, Salmonella typhi and Bacillus subtilis. While all compounds except 9d and 9f were inactive against Shigella flexneri. Compound 9d without any substituent on phenyl ring showed highest antibacterial activity. In all the anti-oxidant assays compounds 9a and 9c containing methyl and methoxy substituent showed good inhibitory activity. The remaining compounds showed moderate anti-oxidant activity. However, it is not possible to give any rational explanation for the antioxidant activities of these compounds even in the absence of essential enolic group. In both lipoxygenase inhibition and PLA2 inhibition assays, compounds 9a bearing methyl group at 4-position of phenyl ring and compounds 9 f and $\mathbf{9 g}$ bearing nitro group at 2- and 4position of phenyl ring respectively exhibited good antiinflammatory activity, the remaining compounds showed moderate activity.

\section{Conclusion}

In summary, we have synthesized a new series of benzisoxazole derivatives in good yields and evaluated for their antibacterial, antioxidant and anti-inflammatory activities. Benzisoxazole derivative without substitution on phenyl ring showed good antibacterial activity against Escherichia coli, Klebsiella pneumonia, Salmonella typhi and Bacillus subtilis. Benzisoxazoles 9a and 9c bearing methyl and methoxy substituents exhibited prominent antioxidant activity and $\mathbf{9 f}$ and $9 \mathbf{g}$ bearing electron withdrawing nitro group showed good anti-inflammatory activity. Thus a new class of benzisoxazole derivatives can be incorporated to the family of bioactive heterocyclic compounds. It should also be noted that, in general compounds bearing activating groups on phenyl ring showed good antioxidant activities, and those with deactivating groups exhibited anti-inflammatory activities.

\section{Acknowledgements}

Authors are grateful to Board of Research in Nuclear Sciences (BRNS), University Grants Commission (UGC) and Indo-French Centre for the Promotion of Advance Research (IFCPAR), Government of India for financial support to Kanchugarakoppal Subbegowda Rangappa under the projects vide No. 2009/37/40/BRNS/2266 dated 23-11-2009 and 39106/2010 (SR) dated 24-12-2010. Chakrabhavi Dhananjaya Mohan thank Department of Science and Technology (DST) for Innovation in Science Pursuit for Inspired Research fellowship and Toreshettahally Ramesh Swaroop thank Council of Scientific and Industrial Research (CSIR) for Junior and Senior Research Fellowship.

\section{References}

[1]. Priya, B. S.; Basappa, ; Swamy, S. N.; Rangappa, K. S. Bioorg. Med. Chem. 2005, 13, 2623-2628.

[2]. Stiff, D. D.; Zemaitis, M. A. Drug Metab. Dispos. 1990, 18, 888-894.

[3]. Uno, H.; Kurokawa, M.; Masuda, Y.; Nishimura, H. J. Med. Chem. 1979, $22,180-188$.

[4]. Gopalsamy, A.; Shi, M.; Golas, J.; Vogan, E.; Jacob, J.; Johnson, M.; Lee, F.; Nilakantan, R.; Petersen, R.; Svenson, K.; Chopra, R.; Tam, M. S.; Wen, Y.; Ellingboe, J.; Arndt, K.; Boschelli, F. J. Med. Chem. 2008, 51, 373379.

[5]. Jain, M.; Kwon, C. H. J. Med. Chem. 2003, 46, 5428-5434.

[6]. Davis, L.; Effland, R. C.; Klein, J. T.; Dunn, R. W.; Geyer, H. M.; Petko, W. M. Drug Design Disc. 1992, 8, 225-240.

[7]. Strupczewski, J. T.; Allen, R. C.; Gardner, B. A.; Schmid, B. L.; Stache, U.; Glamkowski, E. J.; Jones, M. C.; Ellis, D. B.; Huger, F. P.; Dunn, R. W. J. Med. Chem. 1985, 28, 761-767.

[8]. Janssen, P. A. J.; Niemegeers, C. J. E.; Awouters, F.; Schellekens, K. H. L.; Megens, A. A. H. P.; Meert, T. F. J. Pharmacol. Exp. Ther. 1988, 244, 685691.

[9]. Nuhrich, A.; Varache-Lembege, M.; Renard, P.; Devaux, G. Eur. J. Med. Chem. 1994, 29, 75-82.

[10]. Hasegawa, H. Cur. Med. Res. Opin. 2004, 20, 577-586.

[11]. Shantharam, C. S.; Suyoga Vardhan, D. M.; Suhas, R.; Sridhara, M. B. Channe Gowda, D. Eur. J. Med. Chem. 2013, 60, 325-332.

[12]. Villalobos, A.; Blake, J. F.; Biggers, C. K.; Butler, T. W.; Chapin, D. S.; Chen, Y. L.; Ives, J. L.; Jones, S. B.; Liston, D. R.; Nagel, A. A.; Nason, D. M.; Nielsen, J. A.; Shalaby, I. A.; White, W. F. J. Med. Chem. 1994, 37, 2721-2730.

[13]. Rangappa, K. S.; Basappa. J. Phys. Chem. 2005, 18, 773-779.

[14]. Shivaprasad, C. M.; Jagadish, S.; Swaroop, T. R.; Mohan, C. D.; Roopashree, R.; Sharath Kumar, K. S.; Rangappa, K. S. Eur. J. Chem. 2013, 4, 402-407.

[15]. Chuanga, Y. M. D.; Wanga, Y. S.; Kuob, Y. Y.; Tsaia, H. P.; Shyura, W. L. F. J. Ethnopharmacol. 2004, 95, 409-419.

[16]. Halliwell, B.; Gutteridge, J. M. C.; Arnoma, O. L. Anal. Biochem. 1987, 165, 215-219.

[17]. Nishimiki, M.; Appaji, N.; Yagi, K. Biochem. Bioph. Res. Co. 1972, 46, 849-854.

[18]. Shinde, U. A.; Kulkarni, K. R.; Phadke, A. S.; Nair, A. M.; Mungantiwar, D. V. J.; Saraf, M. N. Indian J. Exp. Biol. 1999, 371, 258-261.

[19]. Boman, H. G.; Kaletta, U Biochim. Biophys. Acta 1957, 24, 619-623.

[20]. Gaint, S.; Fitton, A. Drugs 1994, 48, 253-273. 